\title{
Polymorphisms of estrogen receptors, ER $\alpha$ and GPR30: association with breast cancer susceptibility and prognosis
}

\author{
Susana M Alves ${ }^{1 *}$, Luís Mesquita ${ }^{2}$, Rita Sousa ${ }^{3}$, Fátima Peralta ${ }^{2}$, Henriqueta C Silva ${ }^{2,4}$ \\ From 16th International Charles Heidelberger Symposium on Cancer Research \\ Coimbra, Portugal. 26-28 September 2010
}

The purpose of this study was to clarify the roles of polymorphisms from the classical nuclear estrogen receptor ESR1 and from the recently described estrogen receptor coupled to G proteins GPR3O [1], in breast cancer susceptibility and prognosis. Three single nucleotide polymorphisms (SNPs), rs2234693 and rs9340799 from ESR1 and rs3808350 from GPR30 were genotyped in 260 breast cancer patients and 259 controls. SNPs were analyzed by PCR-RFLP and by real-time PCR with TaqMan probes. Genotypes were correlated with established breast cancer prognostic markers. For rs9340799, our results showed a significant association between A allele and breast cancer susceptibility, particularly for homozygous (OR-7.33, 95\%CI, 4.3-12.6; $\mathrm{p}<0.0005$ ). The occurrence of polymorphisms rs2234693 and rs3808350 did not differ between breast cancer patients and controls. However, for rs2234693, CC genotype was significantly associated with higher (G2/G3) tumor grade ( $\mathrm{p}<0,05$; OR-1.01, 95\%CI, 1.01-4.98) and in postmenopausal women, the TT variant was associated with lower (G1) tumor grade ( $\mathrm{p}=0,02$, OR-1.9, 95\% CI, 1.09-3.45). No significant association was found with the presence of estrogen receptors or with HER2 overexpression in tumor samples. In conclusion, our work confirms the role of ESR1 polymorphisms in breast cancer: rs9340799 in breast cancer susceptibility and rs2234693 in breast cancer prognosis. For GPR30 SNP rs3808350, none association was found.

\section{Acknowledgements}

This project was partially supported by CIMAGO.

\footnotetext{
* Correspondence: su_alves_21@hotmail.com

'Department of Life Sciences, Faculty of Sciences and Technology, University of Coimbra, Coimbra, Portugal

Full list of author information is available at the end of the article
}

\section{Author details}

'Department of Life Sciences, Faculty of Sciences and Technology, University of Coimbra, Coimbra, Portugal. ${ }^{2}$ Department of Medical Genetics, Faculty of Medicine, University of Coimbra, Coimbra, Portugal. ${ }^{3}$ Faculty of Medicine, University of Coimbra, Coimbra, Portugal. ${ }^{4}$ CIMAGO, Coimbra, Portugal.

Published: 24 September 2010

\section{Reference}

1. Giess M, Lattrich C, Springwald A, Goerse R, Ortmann O, Treeck O: GPR30 gene polymorphisms are associated with progesterone receptor status and histopathological characteristics of breast cancer patients. J Steroid Biochem Mol Biol 2010, 118:7-12.

doi:10.1016/j.jsbmb.2009.09.001

Cite this article as: Alves et al:: Polymorphisms of estrogen receptors, $E R \alpha$ and GPR30: association with breast cancer susceptibility and prognosis. BMC Proceedings 2010 4(Suppl 2):P6.
Submit your next manuscript to BioMed Central and take full advantage of:

- Convenient online submission

- Thorough peer review

- No space constraints or color figure charges

- Immediate publication on acceptance

- Inclusion in PubMed, CAS, Scopus and Google Scholar

- Research which is freely available for redistribution

Submit your manuscript at www.biomedcentral.com/submit
Biomed Central 